\title{
Geçmişten Günümüze Yahudi Düşüncesinde Kudüs
}

\section{Rabia MERT*}

\section{Jerusalem from the Past to the Present in Jewish Thought}

Citation/C: Mert, Rabia, (2019). Jerusalem from the Past to the Present in Jewish Thought, Milel ve Nihal, 16 (1), 53-70.

Abstract: Although Jerusalem began its place in Jewish history with King David, it was believed that it was promised to Abraham as eternal property by God. In addition, the city was at the center of Jewish religious life as the temple was here. However, Jews always lived under the hegemony of other states after the Babylonian exile, except Hasmoneans period. In this context, it was discussed what they experienced when they were between the culture they lived in and their tradition in various periods and was pointed out different interpretations of Jerusalem in Jewish thought throughout history.

Keywords: Jerusalem, Babylonian Captivity, Zionism, Enlightenment, Secular-

ism.

Atıf/C:: Mert, Rabia, (2019). Geçmişten Günümüze Yahudi Düşüncesinde Kudüs, Milel ve Nihal, 16 (1), 53-70.

Öz: Kudüs'ün Yahudi tarihindeki yerinin Kral Davud ile başlamış olmasına rağmen İbrahim'e Tanrı tarafından ebedi mülk olarak vaat edildiğine inanılmıştır. Ayrıca şehir, mabedin burada olması itibariyle Yahudi dini hayatının merkezinde olmuştur. Bununla birlikte Yahudiler, Babil sürgününden sonra - Haşmoniler dönemi hariç tutulursa- hep başka devletlerin kontrolü altında yaşamışlardır. Bu bağlamda çeşitli dönemlerde içinde yaşadıkları kültürle sahip oldukları gelenek arasında kaldıklarında neler yaşadıkları ele alınmış ve Yahudi düşüncesinde Kudüs'ün tarih içindeki farklı yorumlanma biçimlerine işaret edilmiştir.

Anahtar Kelimeler: Kudüs, Babil Sürgünü, Siyonizm, Aydınlanma, Sekülarizm.

* Dr. Öğr. Üyesi, Sinop Üniversitesi İlahiyat Fakültesi, Din Bilimleri Anabilim Dalı, [rabia_mert_26@hotmail.com]. 


\section{Giriş}

Yahudiliğin tarih içinde pek çok değişimle yüzleşmek durumunda kaldığ1 ve sahip olduğu geleneğin de bu dönemler içinde şekillendiği bilinmektedir. Bu durumun sonucu olarak Yahudi düşüncesinde Kudüs hakkında nasıl bir sürecin yaşandığı ve bu hususta neler söylenebileceği önemli hale gelmektedir. Bu süreç genel hatlarıyla üç kısımda incelenebilir. Öncelikle Yahudilikte Kudüs ideasının nasıl ortaya çıktığına bakıldı̆̆ında belli bir olgunlaşma döneminden söz etmek mümkündür. Şöyle ki bu toprakların Tanrı tarafından Avraam (İbrahim), Yakov (Yakup) ve Isaac'a (İshak) ebedi olarak vaat edildiğine; lakin Avraam ve Moşe (Musa) dönemlerinde Kudüs'ün isminin çeşitli sebeplerle gizli tutulduğuna inanılır. Daha sonra Kudüs'ün görünür olması Kral Davud ve oğlu Süleyman dönemlerinde gerçekleşmiş olup şehir, İsrailoğullarının siyasi ve dini merkezi olarak dikkat çekmiştir. Üçüncü olarak ise Kudüs'ün yıkılması ve idealleştirilmesinden söz edebiliriz; ancak burayı MS 70'deki yıkılışından Aydınlanma dönemine kadar ve Aydınlanma sonrası olmak üzere iki kısımda incelemek uygun olacaktır. Zira Aydınlanma sonrası zuhur eden Siyonizm ile Kudüs'ün geçmiş dönemdeki anlamından farklı bir yorum geliştirilmiştir.

İsrailoğullarının Kudüs'te varlıklarının belirmeye başladı̆̆ı dönemlere bakıldığında şehrin isminin dünyevi krallıkla birlikte anıldığı anlaşılmaktadır. Şöyle ki Kral Davud ile Kudüs'ün siyasi anlamının güçlenmesi ayrıca Süleyman döneminde de mabedin inşası ile şehrin dini öneminin öne çıkmasından sonra İsrailoğulları; krallığ1 Tanrı'nın bir lütfu olarak görmüşler ve krallık ile kutsallığı özdeşleştirmişlerdir. Bununla beraber Kudüs, Babil sürgünü ve mabedin yıkılmasından sonraki diaspora döneminde çeşitli dualarda yer almış ve İsrailoğulları için önemi artmıştır. Tora'da kısa bir dünya tarihi ile yapılan girişten sonra İbrahim'e yapılan atıf ve Musa ile çıkış hep Kudüs'e işaret olarak yorumlanmıştır. Böylelikle sürgünden sonra geçen bütün bir tarih Kudüs fenomeni üzerinden okunmuştur. Bu çerçevede Yahudi düşüncesinde Kudüs'ün önem kazanmasının bir zirve döneminden bahsedilecek olursa bu Süleyman dönemi olacaktır. Bu dönemin en göze çarpan özelliği ise Kudüs'te Tanrı'nın adı için inşa edilen ve Yahudiliğin sembolü olan Bet Amikdaş/Süleyman Mabedi'dir. Bundan sonra Yahudilikten söz ederken Kudüs-mabed teması üzerinden bir anlam arayışının izinin sürülmesi yersiz olmayacaktır. 
Buna karşın Kudüs'teki mabed hakkında çeşitli görüş farklılıkları ile de karşılaşılmaktadır ki bunların ilki Kral Süleyman'ın vefatından sonra gerçekleşmiştir. Kral Yeroboam, Dan ve Beytel'de Kudüs'teki mabede alternatif olarak tapınak inşa ettirmiştir. ${ }^{1} \mathrm{Bu}$ nunla birlikte Yahudilik için önemli bir yere sahip olan Babil sürgününden sonra mabedin yerini Tora'nın/yasa aldığı da bilinmektedir. Üstelik Ezra döneminde mabedin tekrar inşa edilmesinden sonra mabedin olmadığı dönemdeki bazı uygulamaların devam ettirilmesi de dikkat çekicidir. Bu noktada Helen dönemi de seküler hayat anlayışının sonuçlarının Kudüs'e yansıması açısından önem arz etmektedir. Aydınlanma döneminde ise Kudüs, ulus devlet yapısı içinde krallıkla bağlantısından hareketle sembolik anlamı dolayısıyla yer almıştır. Bu dönemde ulusçuluk fikirleri yanında Kudüs'e de atıf yapılması Yahudileri birleştiren en önemli figür olarak görülmesi sebebiyle olmuştur. Daha sonraki süreçte ise Siyonist düşüncenin geliştirdiği Kudüs anlayışı ile karşılaşılmaktadır. Aydınlanma döneminden sonra ortaya çıkan ve ismini Kudüs'teki bir tepeden ve aynı zamanda Yahudilikte Kudüs'ün isimlerinden birisi olan Sion'dan alan Siyonizm, Yahudilere kutsal topraklarda bir devlet kurma ideali taşımaktadır. Yapılan faaliyetler neticesinde şehirde tekrar bir Yahudi varlığı oluşturulmaya çalışılmakla birlikte artık Kudüs'ün dini anlamının fazlasıyla sekülerleştiği gözlenmektedir. Öte taraftan Kudüs'ün İsrail'in başkenti olduğu iddiaları ve buraya yerleşen Yahudi varlığına rağmen mabed inşa edilememiş, kurban ve ibadetler başlamamıştır. Ayrıca bir ibadet dili olan İbranicenin canlandırılması da ulusçuluk fikirleriyle uyumu sebebiyle tercih edilmiştir. Böylece diaspora dönemi boyunca dini bir fenomen olarak anlaşılan Kudüs, 19. yüzyıldan itibaren ulusçuluk fikirleriyle harmanlanarak salt tarihi bir fenomene dönüştürülmek istenmiştir.

Bütün bunlar göz önüne alındığında Yahudi düşüncesinde Kudüs'ün yeri hala eski zamanlarda olduğu gibi midir; yoksa değişmiş midir, sorusu ortaya çıkmaktadır. Bahsedilen hususlar dikkate alınarak Yahudi düşüncesinde Kudüs fenomeninin tarihi süreç içerisindeki yorumlanma biçimleri anlaşılmaya çalışılacaktır.

1 I. Krallar, 12: 28-29 (Kral danıştı ve iki altın buzağı yapıp kavme dedi: Kudüs'e çıkmak sizin için fazladır; ey İsrail, işte seni Mısır'dan çıkaran ilahların. Birini Beyt-el'e ve diğerini Dan'a yerleştirdi.). 


\section{Kudüs'ün Seçilmesinden Babil Sürgünü Günlerine Kudüs}

Yahudi geleneğinde Kudüs'ün merkezini oluşturduğu toprakların İbrahim'e Tanrı tarafından ebedi mülk olarak vaat edildiğine inanılır. ${ }^{2}$ Geleneğe göre İbrahim'e toprakla ilgili verilen vaat, daha sonra oğlu İshak ile de yapılmış ${ }^{3}$ ve üçüncü defa torunu Yakup ile Harran yolunda yenilenmiştir. ${ }^{4}$ Lakin Tora'da vaat edilen topraktan bahsedilmesine rağmen Kudüs'ün ismi geçmez. Bu hususta İbn Meymun; İbrahim, Musa ve diğer peygamberlerin Tapınak Tepesi'nin/Moriah Dağı yerini bildiği halde bunu açıkça söylemediklerini ayrıca İbrahim'in bu yerde bir ibadet evi inşa etmeyi çocuklarına emrettiğini ifade eder. Ayrıca İbrahim'in Kudüs'teki mabedin yerini açıkça söylememesinin üç sebebini sıralamaktadır. Birinci sebep diğer milletlerin onu öğrenmiş olması durumunda işgal edip, onun için savaşmaları tehlikesidir. İkincisi öteki kavimlerin ona sahip olup tahrip etmelerini önlemektir. Sonuncusu ise İsrailoğulları kabileleri onun kendi sınırlarında olmasını isterdi ki bu da onlar arasında çatışma ve bölünmelere sebep olurdu. Bu nedenlerle şehrin isminin bir kral ortaya çıkana kadar açıklanmadığını belirtir. ${ }^{5}$

İsrailoğulları söz konusu döneme ait varlıklarını Kral Davud ile başlatmak arzusundadırlar; çünkü o yaptığı fetih hareketleri sonunda yaklaşık olarak MÖ 997' de Yeruşalim (Kudüs) şehrini alarak onu birleşik İsrail krallığının başkenti yapmış ve Ahid Sandığı'nı da buraya getirmiştir. ${ }^{6}$ Kral Süleyman döneminde inşa edilen mabedi Tanrı'nın kabul ettiğini bildirmesiyle de Kudüs'ün yeni tarihi başlamış oldu. ${ }^{7}$ Ayrıca Kudüs'ün Tanrı tarafından seçildiğinin kabul edilmesinden sonra zaman içinde kurban ibadetinin sadece Kudüs'te

2 Tekvin, 12: 7; 13: 15; 15: 18-21 (Rab Abram'a görünüp dedi: bu toprakları senin zürriyetine vereceğim... Görmekte olduğun bütün memleketi sana ve senin zürriyetine ebedi mülk olarak vereceğim... Rab Abramla ahdedip dedi: Mısır ırmağından Fırat 1rmağına kadar bu diyarı...senin zürriyetine verdim.)

3 Tekvin, 26: 3.

4 Tekvin, 28: 13.

5 Moses Maimonides, The Guide For The Perplexed, trans.: M. Friedlander, (London: Routledge\&Kegan Paul, 1951), c. 3: xlv.

6 Flavius Josephus, The Works of Josephus, trans.: William Whiston, (America: Hendrickson, 1999), Antiquities of The Jews, 7: 3: 1, 2; II. Samuel, 6: 17.

$7 \quad$ II. Tarihler, $7: 16$ (Ebediyen ismim orada olsun diye bu evi seçtim). 
yapılması gerektiğine inanılmıştır. ${ }^{8}$ Görüldüğü gibi İsrailoğullarının Filistin'de bulundukları sürede dini ve milli özellikleri iç içe olup bir de Tanrı ile yapılan akde dayandırılmış ve bütün bunlar Kudüs çevresinde gerçekleşmiştir.

Diğer taraftan Krallık MÖ 925'te ikiye ayrıldığında kuzeydeki İsrail kralı Yeroboam, insanlar Yahuda bölgesindeki Kudüs'e kurban sunmaya gittiğinde ona tabi olurlar korkusuyla Dan ve Beytel'de iki altın buzağı heykeli yaptırmış ve buraları ziyaret etmelerini istemiştir. ${ }^{9}$ Fakat Tanah'ta bu yerlerin Tanrı tarafından kabul edilmediği yer alır. ${ }^{10}$ Ayrıca bu sebeple Tanrısal bir ceza ile de uyarılmışlardır. ${ }^{11}$ İsrail krallığı döneminde Kudüs hakkındaki görüşün nasıl olduğu hakkında Tobit kitabı önemli bilgiler sunmaktadır. Tobit, İsrail kavminin Yeroboam'ın yaptırdığı Dan'da kurban sunduklarını söyler. Kendisi ise kurban sunmak için Kudüs'e gitmektedir; çünkü orada Tanrı evi olan mabedin bulunduğundan kurbanın ancak burada sunulması gerektiğine inanmaktadır. Fakat Kudüs'e çoğu zaman yalnız gitmek zorunda kaldığını da ifade etmektedir. ${ }^{12}$ Sonuç olarak İsrail krallığındaki insanlar tamamen asimile olmuşlardir. ${ }^{13}$

Öte yandan Tanah'ta sürgün öncesinden bahseden bölümlerde Kudüs'ün içinde yer aldığı Yahuda krallığının da İsrail krallığı ile benzer şekilde Tanrı'nın öfkesini çeken davranışlar içinde bulunduğu ifade edilmiş ve Kudüs'ün yıkılması ile uyarılmışlardır. ${ }^{14}$ Uyarıların sonrasında da Tanrı'ya olan ahitlerine bağlı kalmamalarının

$8 \quad$ II. Tarihler, 34: 3-7; 35: 1-6; Adem Özen, Yahudilikte İbadet, (İstanbul: Ayışı̆̆ı Yayinları, 2001), s. 67.

$9 \quad$ I. Krallar, 12: 25-33.

10 Amos, 5: 4 (Rab İsrail'e şöyle diyor, beni arayın yaşarsınız; fakat Beytel'i aramayin Gilgal'a girmeyin.).

11 I. Krallar, 14: 15-16 (Rab İsrail'i bu topraktan sökecek; çünkü aşerleri yaparak Rabbi öfkelendirdiler. Yeroboam'ın işlediği ve İsrail'e işlettirdiği suçları yüzünden Rab İsrail'i bırakacaktır.).

12 Tobit, 1: 1-7 (Tobit kitabından elde edilen bilgiler The Apocrypha, (New York: Thomas Nelson\&Sons, 1804), s. 38'te bulunmaktadir.).

13 Ali Osman Kurt, Fundamentalist Yahudiler, (Ankara: Eski Yeni Yayınları, 2016), s. 18.

14 Yeremya, 25: 5-9 (Şimdi herkes işlerinizin kötülüğünden dönün ve ebede kadar Rabbin size ve atalarınıza vermiş olduğu toprak üzerinde oturun, başka ilahlara kulluk etmeyin... Babil kralı Nebukadnezar'ın bu diyara ve onda oturanlara karşı... onları getireceğim ve bunları yok edeceğim... ve viraneler edeceğim). 
cezası olarak Babil Kralı Nebukadnezar, MÖ 586'da Kudüs'ü ve mabedi yıkmış ve buradaki halkı Babil'e sürgün etmiştir. ${ }^{15}$ Geleneğe göre İsrailoğullarının Kudüs'ten sürülmelerine günahları sebep olmuştur. ${ }^{16}$ Babil sürgünü Tanrısal bir ceza olarak görülmüş ve içinde bulundukları duruma boyun eğmek gerektiği düşünülmüştür. Nitekim sürgün dönemi peygamberleri de bu şekilde söylemiştir. ${ }^{17}$ Buna ek olarak gelenekte Kudüs'e ancak Tanrı'nın eliyle dönüleceği de yer almaktadır ki bu husus Kudüs ve mabedin inşası için ortak bir hareket beklenmesini gerektirmektedir. ${ }^{18}$ Peygamberlerin bir gün Kudüs'e tekrar dönüleceğinden bahsetmeleri Kudüs ve mabed ile ilgili umutların canlı tutulmasını sağlamıştır. ${ }^{19}$ Ayrıca Hezekiel'in mabedin ölçülerini vermesi bu inancı kuvvetlendirmiştir. ${ }^{20}$ Bununla beraber mabed yıkılsa da kutsallığını koruduğuna inanılmaktadır. ${ }^{21}$ Zira Tanah'ta yer alan bilgilere göre Tanrı akdinden dönmez; sadece ceza verir. ${ }^{22}$ Dolayısıyla akdin ebedi olduğu ve geri döndürülmeyeceği kabul edilmiştir.

Bununla birlikte İsrail krallığının yıkılmasından sonra kavmin asimile olduğu bilindiği için Babil sürgününde bazı tedbirler alınmıştır. ${ }^{23}$ Bunun yanı sıra İşaya' da yer alan bilgilerde İsrailoğullarından geriye kalan küçük bir bakiyeden söz edilir ki bunun merkezi Kudüs'tür. ${ }^{24}$ Gelecekte tekrar kurulacak krallığın merkezi olarak Kudüs'ün öne çıkmasında bu hadiseler etkili olmuştur.

II. Krallar, 24: 1-20; 25: 1-6.

Yoma, I, 9b, B.T. (Talmud metinleri The Babylonian Talmud, eds.: Isidore Epstein, (London: The Soncino Press, 1935)'ten alınmıştır.).

Yeremya, 27: 8 (Hangi millet ve ülke Babil kralı Nebukadnezar'a itaat etmezse... o milleti kılıçla, kıtlıkla ve veba ile yoklayacağım).

Kethuboth, XIII, 111a, B.T.

Yeremya, 24: 6 (Onları yine bu diyara getireceğim ve onları bina edeceğim); 32: 37 (Onları sürmüş olduğum memleketlerin hepsinden toplayacağım ve onları bu yere geri getireceğim); Hezekiel, 36: 24 (Sizi bütün memleketlerden toplayacağım ve sizi kendi toprağınıza getireceğim).

Hezekiel, 40.

Yeremya, 41: 1-5 (Gedelya'yı vurduktan sonra ikinci günde Şekem'den Şilo'dan ve Samiriye'den adamlar Rab evine getirmek üzere ekmek takdimesi ve günnük ellerinde olarak seksen kişi geldiler).

Yeremya, 3: 14-19 (Sizi alıp Sion'a geri getireceğim... atalarınıza miras olarak vermiş olduğum diyara birlikte geleceksiniz).

Yusuf Besalel, Yahudi tarihi, (İstanbul: Gözlem Yayınevi, 2003), s. 54. İşaya, 1:9. 
Babil sürgününden yaklaşık 70 yıl sonra Pers kralı Koreş, Babil imparatorluğuna son vererek burada sürgünde bulunan Yahudilerin Kudüs'e dönmelerine ve mabedi yapmalarına izin veren bir fer-

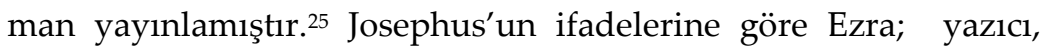
Musa kanunları hakkında bilgili ve dürüst bir adam olup Pers kralından Kudüs'e gitmek için izin istemiştir. ${ }^{26}$ Ezra ve Nehemya öncülüğünde mabedin yeniden inşası için çalışılmış ve ibadetler tekrar uygulanmaya başlamıştır. ${ }^{27}$ Burada şu hususu da belirtmek gerekmektedir. Babil'de sürgün dönemlerinde Hezekiel'in evinde toplanılmaya başlanmıştır. ${ }^{28}$ Daha sonra bu uygulama sinagog/dua evine dönüşmüştür. Dikkat çeken ise mabedin tekrar inşa edilmesine rağmen sinagogların devam etmesidir. Ayrıca mabed inşa edilip kurban ibadeti başlamasına rağmen Ezra tarafından bazı dua ilaveleri de yapılmıştır. Bunlar; Şabat günü öğleden sonra, pazartesi ve perşembe günleri toplu olarak Tora'dan okumalar yapılmasıdır. ${ }^{29}$

Bununla beraber Ezra, şehre geldiğinde fiziksel olarak mabedin ikinci defa inşa edilmesi yanında başka bir hususla da yakından ilgilenmiştir. O da İsrailoğullarının Tora'ya uygun yaşamaları için kanun ve hükümlerin uygulanmasının gerekliliğidir. Çünkü mabedin ancak Yasa' nın hükümleri uygulandığı vakit gerçek anlamına kavuşacağına ve tam olarak inşa edilmiş olacağına inanmaktadır. Böylece mabedin olmadığı, Babil sürgünü döneminde başlayan Yasa'ya verilen önemin devam ettirildiği görülmektedir.

\section{Helen Döneminde Kudüs'ün Konumu}

MÖ 586'dan MS 70'e kadar geçen sürede Kudüs, politik öneminden ziyade dini bir merkez olarak kalmıştır. Diğer bir deyişle Pers kralı Koreş'in emriyle mabed yeniden inşa edilmiş buna karşın bölge Pers yönetimine bağlı kalmaya devam etmiştir. Ayrıca Yahudiler, Perslilerin hâkimiyeti altında iken kendi hukuklarını uygulama hakkına sahiplerdir ve bu süreç Büyük İskender'in bölgeyi ele geçirmesinden sonra başlayan Helen döneminde de benzer şekilde olmuştur. İskender'in ölümünden sonra başlayan Ptolemy hanedanı

\footnotetext{
Ezra, 1: 5; Josephus, Antiquities of The Jews, 11: 1: 1.

Josephus, Antiquities of The Jews, 11: 1.

Nehemya, 2: 17; Josephus, Antiquities of The Jews, 11: 5: 7-8.

Hezekiel, 20: 1.

Baba Kama, 82a, B.T.
} 
döneminde ise Yahudiler, Kudüs'te Musa yasalarını uygulamışlardır; ancak bir süre sonra Helen etkisi Kudüs'e ulaşmıştır. ${ }^{30}$ Bazı Yahudiler Grek kültüründen etkilenirken diğerleri bundan uzak durmuşlardır. Kudüs ise bu iki görüşün müntesipleri arasındaki mücadelede en tartışmalı kısmı oluşturmuştur. Kısaca belirtmek gerekirse Helen kültürü seküler anlayışa sahiptir ve bunun topluma bazı yansımaları vardır. Örneğin ülkenin en ücra köşelerine kadar Helen okulları açılmış ve Hermes ile Heracles onuruna olimpiyat oyunları düzenlenmiştir. Bu yönüyle Helen kültürü Musa yasalarına bağlı olan Yahudilerin geleneklerinden uzaklaşmalarına sebep olmuştur. ${ }^{31}$

Yukarıda ifade edildiği gibi Ezra döneminde Pers hâkimiyetine bağlılık devam etmiş; bununla birlikte mabedin yeniden inşa edilmesiyle dini merkez canlandırılarak ibadetler tekrar başlatılmıştır. Lakin Yahudiliğin Helen kültürü ile karşılaşmasında durum biraz daha farklı olmuştur. Şöyle ki Babil sürgününde bazı insanlar Kudüs'e gelmeyi reddederek orada kalmayı tercih etse de İsrailoğullarının önemli bir kısmı Kudüs'e gelmiş ve sürgün öncesine dönülmeye çaba gösterilmiştir. Helen döneminde ise bizzat İsrailoğullarının eliyle hatta Kudüs'te mabedin yanında Grek kültürü görülmeye başlamıştır. İsrail halkından pek çok kişi Roma adetlerine uymuştur. Romalı idareciler de onlara bu konuda izin vermiştir. Bunun sonucunda Romalı isimleri kullanmaya başlamışlar, Yahudi olduklarını ise gizlemişlerdir. Üstelik Helen kültürünü benimseyen yüksek rahip Jesus tarafından mabedin yanına bir gymnaisum (hem zihinsel hem fiziksel gelişime önem verilen lise) bile inşa edilmiştir. ${ }^{32}$ Diğer taraftan Kudüs ve diaspora halkları arasındaki ilişki bozulduğunda ve Kudüs'ün rakip kimselerin egemenliği altında olduğu kabul edildiğinde başka mabedlerin kurulması düşüncesi de ortaya çıkmıştır. ${ }^{33}$ Örneğin İskender, Manasse'ye kardeşi Jaddus için Samiriye'de mabed inşa etme ve rahiplik etme izni vermiştir. ${ }^{34}$

\footnotetext{
30 Josephus, Antiquities of The Jews, 11: 1: 1-3; 11: 8: 5; 12: 1: 1.

31 Karen Armstrong, Jerusalem One City Three Faith, (United States Of America: Ballantine Books, 1996), ss. 104-113.

32 Josephus, Antiquities of The Jews, 12: 5: 1.

33 Martin Hengel, Judaism and Hellenism, trans.: John Bowden, (Philadelphia: Fortress Press, 1981), s. 12.

34 Josephus, Antiquities of The Jews, 11: 8: 4.
} 
Yine Saduki rahiplerinden birinin -muhtemelen III. Onias- Kudüs'ten kaçıp belli bir Yahudi nüfusun bulunduğu Misır'da rakip bir mabed kurduğu da bilinmektedir. ${ }^{35}$

Ptolemy hanedanından sonra bölgeyi ele geçiren yine Helen kültürüne ait Selevkoslar yönetiminde Kudüs'teki halk, başlangıçta seküler hayattan etkilenmeye devam ederken sonrasında çeşitli yaptırımlarla karşılaşmışlar ve Helen kültürüne tabi olmaya zorlanmışlardır. Bu bağlamda IV. Antiochus, mabedde kurban sunulmasını yasaklamış, kutsal metinleri imha ettirmiş ve ibadetleri yasaklamıştır. Mabedin kandillerini, kazanlarını, masayı ve diğer eşyaları yağmalamıştır. Mabede Yunan Tanrı'larına ait heykelleri yerleştirmiş ve itaat etmeyenlerin ölüm ile cezalandırılmasını emretmiştir. ${ }^{36}$ Böyle bir durumun nasıl karşılandığına bakıldığında yüksek rahip Simon'un kuşatmaya karşı şehrin savunmasını güçlendirdiği ve mabedi onardığ 1 bilgisi ile karşılaşılmaktadır. ${ }^{37}$ Mabedin onarılması görevi olmadığı halde yüksek rahibin böyle bir işe kalkışması Selevkoslar'a karşı olduğunu göstermektedir. Ne var ki bunu politik bir amaçla değil sadece mabedin kutsallığını korumak isteğiyle gerçekleştirdiği de bilinmelidir. Burada şu hususun belirtilmesi gerekir ki Selevkoslar döneminde Kudüs bölgesindeki Yahudiler yüksek rahiplik ile temsil edilmişlerdir. Dolayısıyla Helen döneminde yüksek rahiplik, Kudüs politikasında önemli bir yere sahiptir. Buna karşın yüksek rahiplik sadece sembolik olarak görülmüştür. Aslında geleneğe göre bu görev Harun soyundan gelenlere aittir.

Selevkoslara karşı diğer tepki Makkabiler/Haşmoniler önderliğinde gerçekleşmiş olup silahlı bir isyan başlatılmıştır. Bu hareket pagan adetlerine karşı olup Musa yasalarına göre yaşamayı savunmaktadır ve temelde Helenizm'e karşıdır. Bununla beraber Yahudilerden Haşmoniler destekleyenler ve karşı olanlar vardı. Fakat çatışmaya başladıklarında IV. Antiochus'un baskılarının etkisiyle çoğunluğun desteğini almış durumdaydılar. Roma güçlerini yenip

35 E. P. Sanders, Judaism Practice \& Belief 63 BCE-66CE, (London: SCM Press, 1992), s. 23.

36 Josephus, Antiquities of The Jews, 12: 5: 3-4; The Five Books of Maccabees, trans.: Henry Cotton, (Oxford: Oxford University Press, 1832), I. Maccabees, I: 35-50.

37 Ecclesiasticus (Ben Sira), 50: 1-4 (Ecclesiasticus kitabından elde edilen bilgiler The Apocrypha, (New York: Thomas Nelson\&Sons, 1804), ss. 78-119 arasında bulunmaktadır.). 
mabedin yanına geldiklerinde ise onu harap bir halde bulmuşlardır. Altarın/mezbah kirletildiğini ve mabedin kapılarının yakıldığını görmüşlerdir. Daha sonra mabedi onarmışlar, içini düzenlemişler ve tekrar kurban ibadetini gerçekleştirmişlerdir. Romalıların buna cesaret edebilmelerini ise Tanrı'nın Kudüs halkına günahlarından dolayı öfkeli olduğu ve kendileriyle ilgilenmediği şeklinde açıklamışlardır. ${ }^{38}$

Haşmonilerin yaklaşık bir asır süren hâkimiyetinden sonra MÖ 63'te Pompey komutasındaki Roma güçleri yönetimi tekrar ele geçirmiştir. ${ }^{39} \mathrm{Bu}$ dönem 66' da savaş başlayana kadar devam etmiştir. İsyanın sebebi Roma valisinin tarafından mabed hazinesinden para istenmesi, çeşitli hakaretler, haksızlıklar ve ölümlerdir. Bu bağlamda politik olarak Roma'ya bağlı olan halk, Kudüs'ün kutsallığını korumak ve kutsalın kirletilmesine karşı çıkmak istemiştir. ${ }^{40}$ Aynı şekilde Kudüs'teki mabede imparatorun heykelinin yerleştirileceği duyulduğunda sadece Filistin bölgesindeki Yahudiler değil Yunanca konuşan Yahudilerin de tepki gösterdiği bilinmektedir. Pek çok dini ve aristokratik destekçinin bulunduğu Kudüs'teki mabedde, genel meclis toplanarak Ananus'u lider olarak atamıştır. Sonrasinda ise MS 70'de Titus komutasındaki Roma kuvvetleri tarafından şehir harap edilmiş ve mabed yıkılmıştır. Roma ile yaşanan savaşta Kudüs, mabed olduğu için yıkılırken; mabedin ise yüksek rahipliğin burada bulunması sebebiyle yakıldı̆̆ı anlaşılmaktadır. Ayrıca mabedin ikinci büyük tahribinden sonra kurban ibadetinin askıya alınması sebebiyle mabed çevresinde merkezileşen Sadukiler de zaman içinde kaybolmuştur. Ferisiler ise Tora'yı kutsal toprak temasından daha önemli kabul etmişlerdir. Böylece ibadette yetki de kâhinlerden hahamlara geçmiş oldu. ${ }^{41}$

Bu noktada Philo'dan bahsetmek uygun olacaktır. Zira Philo, diasporada bulunan ve Yunanca konuşan Helen Yahudisi olmasına rağmen yaşanan haksızlıklar üzerine ricada bulunmak amacıyla imparatora elçi olarak gitmiş biridir. ${ }^{42}$ Ayrıca o, mabedde dua etmek

\footnotetext{
38 I. Maccabees, IV: 38-56.

39 Sanders, Judaism Practice \& Belief 63 BCE-66CE, s. 19.

40 Sanders, Judaism Practice \& Belief 63 BCE-66CE, s. 39.

41 Francine Kaufmann ve Josy Eisenberg, "Yahudi Kaynaklarına Göre Yahudilik", Din Fenomeni, çev.: Mehmet Aydın, (Konya: Din Bilimleri Yayınları, 2000), s. 101.

42 Dursun Ali Aykıt, Hiristiyanlı̆̆ın Öncüsü Olarak İskenderiyeli Philo, (İstanbul: Kitabevi Yayınları, 2011), s. 30.
} 
ve kurban sunmak için Kudüs'ü de ziyaret etmiştir. ${ }^{43}$ Philo'ya göre Kudüs, Tanrı tarafından Yahudiler için seçilmiştir ve Tanrı ile insanlar arasındaki ilişkileri temsil etmektedir. Onun görüşlerinde $\mathrm{Ku}$ düs, Yahudi kavminin ve dininin sembolü olarak anlam ifade etmektedir. Bu bağlamda Kudüs'ün anne olduğunu bu sebeple Yahudiler için Sion'un kızı denildiğini söyler. ${ }^{44}$ Ayrıca onun Kudüs'ün iki anlamından söz ettiği görülür. Buna göre birinci anlamı dünyada ikincisi ise ruhtadır. ${ }^{45}$ Bununla birlikte Kudüs'te mabed olduğu için şehrin önemli olduğunu belirterek onu kutsal şehir olarak adlandırmış ve mabedde kurbanlara engel olunmamasını ve barışın korunmasını istemiştir. ${ }^{46}$

Öte taraftan sürgün döneminde Kudüs ve mabed temalarına yönelik ilgi eskatolojik mesih beklentisini etkilemiştir. Başka bir deyişle Tanah ve Talmud'da mesih hakkında ifadeler olmakla birlikte mabedin ikinci tahribi mesih anlayışını güçlendirmiştir. ${ }^{47}$ Yahudilerin mabedin ikinci kez tahribinden sonra bir daha inşa etme teşebbüsünde bulunmamalarının sebebi daha önce ifade edildiği üzere gelenekte yer alan sürgün döneminde devlet kurmaya teşebbüs etmelerinin yasaklanmasıdır. Talmud'da yer alan ifadelere göre sürgün başladığında Tanrı, İsrailoğullarından üç söz almıştır. Bunlar; Filistin'e toplu olarak dönmemeleri, sürgün oldukları ülkeye isyan etmemeleri ve Kudüs civarında bir devlet kurmaya kalkışmamalarıdır. ${ }^{48} \mathrm{Bu}$ anlayış Aydınlanma dönemine kadar bir şekilde devam ettirilmiştir.

\section{Aydınlanma Dönemi Düşüncesinde Kudüs'ün Anlamı}

Aydınlanma döneminde din yerine insan merkezli düşünceler önem kazanmaya başlayınca Yahudilerin sosyal hayatında da bazı iyileştirmeler gerçekleştirilmiştir. Bununla birlikte Avrupa'da yaşayan Yahudiler, hem sunulan imkânlardan yararlanmış hem de bu dönemin fikirlerden etkilenmişlerdir. Aynı zamanda ortaya çıkan bu durum Yahudilik için bir meydan okuma şeklinde de anlaşılabi-

\footnotetext{
43 Philo, trans.: F. H. Colson, (Massachusetts: Harward Press, 1985), On Providence, 2: 64 .

44 Curtis E. Adkins, Jerusalem: The Chosen City Seven Studies on the Symbolism of the City, (Unpublished Ph. D. thesis, Fuller Theological Faculty, 2011), s. 152, 158.

45 Philo, On Dreams II, 246-258.

46 Philo, The Embassy to Gaius, XXXVI: 278, 288; XL: 313.

47 İşaya, 11: 1-10.

48 Kethuboth, XIII, 111a, B.T.
} 
lir. Çünkü Yahudilik sadece dogmalardan ibaret olamayıp aynı zamanda bir gün ataların yurduna dönüp mabed çevresinde ibadet etmeyi umut eden bir gelenektir. Bu noktada Fransız devrimi sonrası Yahudilere verilen vatandaşlık hakkı ile bir Yahudinin dinini kaybetme tehlikesi ortaya çıkmıştır. Bu konu evrensel insan haklarında yer alan din özgürlüğü ile çözülmeye çalışıldı. Rabbani Yahudilik, Tanrı ile İsrailoğulları arasında yapılan ahid gereğince dindar bir krallık ve kutsal bir ulustan bahsetmesi sebebiyle politik bir organizasyona benzemektedir ki bu haliyle devlet içinde devlet görünümü sunmaktadır. Ayrıca İsrailoğulları özel bir toprakla da ilişkilendirilmiştir. Bahsedilen durumun modernite bağlamında sorunlu hale gelmesi neticesinde Yahudilikteki politik unsurların reforme edilmesi düşünülmüştür. ${ }^{49} \mathrm{Bu}$ yönüyle politik unsurların eleştirilmesi Yahudi düşüncesi hakkında önemli fikirler vermektedir.

Bu çerçevede Avrupa merkezli Aydınlanma sürecinin eşitlik ve özgürlük gibi temalarının etkisiyle ve Yahudilere tanınan eşit vatandaşlık haklarının sonucunda Reformist Yahudi hareketi ortaya çıkmıştır. Bu hareket Yahudiliği modern dönemin şartlarına uyumlu hale getirme arzusunda olmuş, Almanya'da başlayıp daha sonra Avrupa ve Amerika'ya yayılmış ve en güçlü cemaatini de ABD'de oluşturmuştur. Artık Yahudilik bir din olarak görülmenin yerine dini topluluk olarak kabul edilmiştir. ${ }^{50}$ İçinde yaşadıkları kültürle sahip oldukları gelenek arasında bir uzlaşma zemini arayan bu hareket, zamanla dini özelliklerinden uzaklaşmaya başlamıştır. Yahudilikte yer alan bazı hususların aklın süzgecinden geçirilmesiyle birlikte (Talmud'un otoritesinin reddedilmesi gibi) çeşitli değişiklikler yapmanın gerekliliğini hissetmişlerdir. Öyle ki bazı Reformist Yahudiler, Avrupa toplumu ile bütünleşebilmek için Yahudilik ile Kudüs'ün arasını ayırmayı düşünmüştür. ${ }^{51}$ Aynı şekilde seçilmişlik ve mesih fikirleri de yeniden yorumlanmış, bunun sonucunda da kutsal topraklara dönüş ve mabedin inşa edilmesi düşüncesinden uzaklaşmışlardır. Hatta mesih ve kutsal topraklara dönüş temaları

49 Jerome Eric Copulsky, Between Exile and Redemption: Political Theology and the Shaping of Modern Jewish Thought, (Unpublished Ph. D. thesis, University of Chicago, 2005), s. 3, 4, 6, 7.

50 Salime Leyla Gürkan, "Yahudi Geleneğinde Reform Arayışları", Milel ve Nihal: İnanç, Kültür ve Mitoloji Araştırmaları Dergisi, 5/2, 2008, ss. 156-157.

51 Kaufmann, "Yahudi Kaynaklarına Göre Yahudilik", s. 115. 
dua kitaplarından çıkarılmıştır. ${ }^{52}$ Reformist Yahudiler, 1845 Frankfurt konferansında kutsal topraklara dönüş, kurbanın yeniden başlaması ve tekrar bir Yahudi devletinin kurulması konusundaki görüşleri reddetmişlerdir. Ayrıca gelenekte yer alan Yahudilerin günahları sebebiyle sürgün edildiklerine dair yorumu da Tanrı'nın adını her yere duyurmak için diğer yerlere gönderildikleri şeklinde anlamışlardır. ${ }^{53}$ Özetle Reformist Yahudiler Kudüs'te yaşamasalar, Yahudi devleti mevcut olmasa dahi yasanın hükmünün kaybolmadığını; bununla birlikte sadece kişilerle ilgili olanların uygulanabileceğini iddia etmişlerdir.

Burada Yahudi Aydınlanma hareketinin/Haskala öncüsü kabul edilen, batı değerleri ile Yahudilik arasında bir sentez oluşturmak isteyen Moses Mendelssohn'un etkisinden söz etmek gerekmektedir. Mendelssohn, Jerusalem adlı kitabında Yahudiliğin modern dönemin anlayışı ile uyum sağlayabileceğini iddia etmiştir. Bunu yaparken Yahudiliğin yasaları ile ahlaki değerleri arasında bir ayrıma gitmiş, konuyu din ile devlet üzerinden incelemiş ve dinin devlete devletin de dine müdahale etmemesi gerektiğini savunmuştur. ${ }^{54}$ Mendelssohn, dinin insanlar üzerindeki yetkisini yitirdiğini kabul ederek bireysel anlamda inanca yer açmaya çalışmıştır; yani ona göre Kudüs, Yahudi devletini ifade etmeyip sadece Yahudilerin manevi vatanıdır.

Diğer taraftan Avrupa toplumunun, Fransiz ihtilalinden sonra gerçekleşen özgürlük ortamının getirdiği çeşitli haklardan Yahudilerin yararlanmasına henüz hazır olmadığını gösteren bazı antisemitik olaylar yaşanmıştır. Yahudilerin öteki olarak algılanmaya devam etmeleri sonucunda bir kısım Yahudi sosyalizme diğer bir kısmı da milliyetçi hareketlere katılarak olaylara çözüm aramışlardır. Bu dönemin Yahudi düşünürleri, diğer milletler arasındaki yerlerini açıklamak aynı zamanda geçmişleri ile dinleri arasındaki bağı da ifade etmek istemişlerdir. Bunun yanında amaçları bugüne dair yeni bir bakış açısı geliştirmektir. ${ }^{55}$ Ulusçuluk görüşleri modern dönemde Yahudilerin bir devlet fikrine sahip olmalarını sağlamıştır.

52 David Philipson, “The Frankfort Rabbinical Conference 1845”, The Jewish Quarterly Review, 18, 2, 1906, ss. 274-275.

53 Philipson, “The Frankfort Rabbinical Conference 1845", s. 266, 267, 273.

54 Moses Mendelssohn, Jerusalem or on Religious Power and Judaism, trans.: Allan Arkush, (Massachusetts: Brandeis University Press, 1983), s. 33, 118.

55 Efraim Shmueli, "The Jerusalem School of Jewish History", American Academy for Jewish Research, 53, 1986, s. 148. 
Buna göre Yahudilerin sorunu siyasidir. Bu durumda sürgün metaforu anlamını yitirmekte ve mesihi beklemek manasız hale gelmektedir. Başka bir ifadeyle artık Kudüs'ün sembolik olduğuna inanılmakta, Kudüs ve mabedin yıkılmasından sonra insanların yasaya bağlı kalmalarının istenmesi de bunun işareti kabul edilmektedir.

Bütün bunların neticesinde politik bir harekete dönüşen Siyonizm ortaya çıkmıştır. Siyonistler, Batı kültüründen edindikleri liberal görüşleri Filistin topraklarına taşımak suretiyle gelenekteki kutsal toprak temasını laik devlet anlayışına çevirmişlerdir. Bazı hahamlar ise Kudüs çevresinde kurulacak bir devleti desteklemiş, bunu da mesih öncesi döneme hazırlık olarak açıklamışlardır. ${ }^{56}$ Siyonizm, önceleri milliyetçi kaygılarla hareket ederken daha sonra kendisine dini temel bulma ihtiyacı içinde olmuştur. Böylece içinde yaşadıkları topluma uyum sağlamak adına ötelenen Sion/Kudüs teması tekrar öne çıkarılmıştır. Bununla birlikte Siyonistlerin Kudüs'e yönelik ilgilerini şöyle ifade etmek mümkündür, Tanr yok ve bu toprakları bize söz verdi. ${ }^{57}$ Bundan böyle Siyonist Yahudiler için Kudüs ismi, gücünü Yahudi ırkının tarihsel köklerinden alacaktır.

Yahudiliğe göre İsrailoğullarının kaderi Tanrı ile yapılan ahdin sonuçlarını ifade etmektedir. Vaat edilen topraklardan sürgün edilmeleri de ahitlerine sadık kalmamaları sebebiyle Tanrı'nın bir cezası olup geri dönmeleri ise tevbe etmelerine bağlıdır. Geleneğe ait bu yorumlar Siyonistler tarafından reddedilmiştir. Onların bu yeni tarih okumalarında Tanrı'nın otoritesi tarihin otoritesi ile değiştirilmiş ve Kudüs civarında seküler bir Yahudi yerleşimi oluşturulmuştur. Bu duruma en fazla muhalefet de yine geleneğe bağlı Yahudilerden gelmekte ve kutsal topraklarda insan eliyle bir devlet kurulması Tanrı'ya verilen sözün ihlal edilmesi olarak görülmektedir. ${ }^{58}$

Öte yandan Yahudiler, Avrupa'da yaşanan antisemitik hareketlerin etkisiyle Amerika'ya göç etmeye başlamışlardır. Amerika'da bulunan Yahudiler ise önceleri Siyonizm'e uzak durmuşlar,

\footnotetext{
56 Kaufmann, "Yahudi Kaynaklarına Göre Yahudilik", s. 112, 119.

57 Yakov M. Rabkin, "Judaism: The Search for Peace in the Holy Land", Holy Land Studies 10, 2, 2011, s. 139.

58 Rabkin, "Judaism: The Search for Peace in the Holy Land", s. 145, 151, 152.
} 
hatta vaat edilmiş toprak olarak Kudüs'ü değil Amerika'yı gördüklerini Amerika bizim Kudüs'ümüzdür, diyerek belirtmişlerdir. ${ }^{59}$ Sion kelimesi dua kitaplarında geçiyordu; lakin önceleri Siyonist kelimesi onlar için hiçbir anlam ifade etmiyordu. Üstelik bütün Yahudileri Filistin'e götürme iddiasına ise sadece gülünürdü. ${ }^{60}$ Fakat daha sonra Siyonizm kelimesini sıkça duymaya ve Siyonist düşüncelerden etkilenmeye başlamışlardır. II. Dünya savaşının başlaması ile artan olaylar Yahudiler için bir devlet bulma fikrinin yaygınlaşmasını sağlamış, Amerikalı Yahudiler de Kudüs civarında yaşamak istememelerine rağmen gelinen noktayı kabul etmek durumunda kalmıştır. ${ }^{61}$

Bütün bunlardan anlaşıldığı üzere Aydınlanma döneminin insan merkezli fikirlerinden etkilenen Yahudiler, ulus kimliğini reddederek dini topluluk olduklarını ifade etmişler ve dini öğelere geleneğin dışında yorumlar geliştirmişlerdir. Aynı zamanda Kudüs'e verilen önemin de yönü değişmiştir. Buna karşın antisemitik hareketlerden sonra Siyonizm'in güçlenmesi ile bir devlet arayışında Kudüs fikri tekrar hatırlanmıştır. Yine bu durumun ulus kimliğini reddeden Yahudiler için kaygı verici olduğu da belirtilmelidir.

Aydınlanma döneminden Siyonizm'e dönüşen süreci anlamak için Pittsburgh ve Columbus platformlarına daha yakından bakmak uygun olacaktır. 1885 tarihinde gerçekleşen Pittsburgh platformunda Yahudilerin ulus mu yoksa dini topluluk mu olduğu tartışılmış, burada Kudüs hakkında görüşlere de yer verilmiştir. Beşinci maddede; Kendimizi artık ulus olarak değil, dini bir topluluk olarak görüyoruz. Ne Filistin'e dönüşü ne de kurban ibadeti ve Yahudi devleti ile ilgili yasaların tekrar başlamasın beklemiyoruz, denilmek suretiyle Kudüs'e dönüş fikrinden uzaklaştıklarını açıkça ifade etmişlerdir. Bu

59 Marc Lee Raphael, "Rabbi Jacop Voorsanger of San Francisco on Jews and Judaism: The Implications of the Pittsburgh Platform", American Jewish Historical Quarterly, 63, 2, s. 201.

60 Sholem Aleichem, Stories and Satires, London: Hardcover, 1999, ss. 222-225 (Mesihin gelmesini ve bizi sürgünden kurtarmasını, babalarımızın diyarına, İsrail toprağına götürmesini bekledik. İki bin yıldır 17 tamuz bayramını kutluyoruz. Şimdi soralım Sion uğruna ne verdik ve Kudüs uğruna. Yakub'un evine gidelim. Ne bir mucize ne de büyük bir adam beklemeyelim. Eğer büyük adamı beklersen beklemeyi sürdüreceksin. Biz kendi şanlı evimizi inşa etmeye başlamalıyız.)

61 Seda Özmen, "Reform Yahudiliğinin Pittsburgh ve Columbus Platformları Bağlamında Değişen Kutsal Topraklara Dönüş İnancı", İsrailiyat: İsrail ve Yahudi Çalışmaları Dergisi, 2, 2018, ss. 94-96. 
platformda içinde yaşanılan topluma uyum sağlama çabası öne çımıştır. Şöyle ki üçüncü maddede, Musa yasalarından sadece ahlaki olan hususların bağlayıcı olduğu kabul edilerek modern yaşama uymayanlar reddedilmiştir. ${ }^{62}$ Yani evde Yahudi, dışarda Alman, Macar veya Fransız olmak şeklinde özetlenebilecek bir anlayışa rastlanmaktadır.

1937 tarihli Columbus platformunda ise bir anlamda geleneksel değerlere tekrar yaklaşıldığı görülmektedir. Beşinci madde/İsrail maddesi şu şekildedir: Yahudilik bir ruhtur, İsrail onun bedenidir, Filistin'in yeniden inşasinda anılar ve ümitlerle dolu topraklarda yeni bir yaşam vaat ediyoruz. Sadece ezilenler için değil, Yahudiliğin manevi merkezi olması için de çalışarak bir Yahudi ülkesi olması için çalışacağız. Tanrı'nın krallı̆̆ının kurulmasında herkesle işbirliği yapmayı tarihi görevimiz olarak görüyoruz. Bu bizim mesihi görevimizdir. ${ }^{33}$ Bundan sonra Siyonist düşünce güçlenmekle birlikte Kudüs'e yönelik ilgi de artık eskiden olduğundan farklı bir boyut taşımaktadır.

Yukarıda ifade edilen bilgilerde görüldüğü gibi İsrail'de bir devlet kurma girişiminde bulunan Yahudiler -mesih inancına karşı olacak şekilde- geleneğe bağlı olmayan insanlardır. Lakin kendilerine tuhaf bir şekilde geleneğin en dikkat çeken mekânında yer aradılar. $\mathrm{Bu}$ da aslında uzaklaşmak istedikleri geleneğin içine çekilmeleri anlamına geliyordu. Bununla birlikte Yahudiliğin idealinde olan mekânın bizzat Yahudiler eliyle sekülerleştirilmesiyle yüzleşilmiş oldu. Diğer bir ifadeyle Yahudilerin kutsal topraklarında şimdi seküler bir devlet bulunuyor.

Bütün bu süreçlerin sonunda günümüzde Yahudilerin Kudüs hakkında ne düşündüklerini anlamak amacıyla 1965'ten 1993'e kadar Kudüs Belediye Başkanlığını yürüten Teddy Kollek'in görüşlerine bakılabilir. Ona göre Ortadoğu'nun problemleri çözüldüğünde Kudüs, gündemdeki en son konular arasında yer alacaktır. Bunun için önerileri ise milliyetine bakılmaksızın herkese kutsal mekânlara özgür giriş hakkı tanınması ve inananları tarafından idare edilmesi, şehrin Arap kesiminde Müslümanların ve Hıristiyanların dini, kül-

62 www.ccarnet.org/rabbinic-voice/platforms/article-declaration-principles/(03.02.2019).

63 www.ccarnet.org/rabbinic-voice/platforms/article-guiding-principles-reform-judaism/(03.02.2019). 
türel ve ticari hayatının geliştirilmesi ve her grubun kültürel ve ulusal kimliğini korurken Kudüs'teki farklı gruplar arasındaki kültürel, sosyal ve ekonomik ilişkilerin geliştirilmesinin sağlanması yönündedir. ${ }^{64}$ Böylece şehirdeki yaşam kalitesini artırarak var olan problemlerin barış içinde çözülebileceğini iddia etmektedir. Lakin Mescidi Aksa ya da Batı Şeria/el-Halil'da olduğu gibi aynı mekân üzerinde birden fazla dinin kutsallık iddiasında bulunduğu alanlarla ilgili olarak mevcut sorunların nasıl çözüleceği hakkında yeterli açıklama sunamamaktadır.

\section{Sonuç}

Özetle günümüzdeki Yahudilerin birkaç görüşe sahip olduklarını söylemek gerekmektedir. Ortodokslar, Kudüs'te bir devlet kurulmasının Tanrı'ya isyan olduğuna inanmaktadır. Bununla beraber Tanrısal kurtuluşu beklerken bir yandan da bunun için çaba göstermeye başlamışlardır. Diğer bir grup olan Ultra Ortodoks Yahudilere göre sürgün, İsrailoğullarının günahlarının cezasıdır, bunun son bulması da ancak Tanrı'nın müdahalesi ile olacaktır. Bunun için herhangi bir çabada bulunmak da günah kabul edilir. Siyonistler ise geleneksel sürgün ve kurtuluş anlayışını reddederek bir devlet kurmak iddiasındadırlar. ${ }^{65}$

\section{Kaynakça}

Adkins, Curtis E. Jerusalem: The Chosen City Seven Studies on the Symbolism of the City, (Unpublished Ph. D. thesis, Fuller Theological Faculty, 2011).

Aleichem, Sholem. Stories and Satires, London: Hardcover, 1999.

Aykıt, Dursun Ali. Hıristiyanlığın Öncüsü Olarak İskenderiyeli Philo, İstanbul: Kitabevi Yayınları, 2011.

Armstrong, Karen. Jerusalem One City Three Faith, (United States Of America: Ballantine Books, 1996).

Copulsky, Jerome Eric. Between Exile and Redemption: Political Theology and the Shaping of Modern Jewish Thought, (Unpublished Ph. D. thesis, University of Chicago, 2005).

Gürkan, Salime Leyla. "Yahudi Geleneğinde Reform Arayışları", Milel ve Nihal: Inanç, Kültür ve Mitoloji Araştırmaları Dergisi, 5, 2, 2008, ss. 147159.

\footnotetext{
64 Teddy Kollek, "Present and Future", Council on Foreign Relations, 59, 5, 1981, s. 1041.

65 Kurt, Fundamentalist Yahudiler, ss. 321-322.
} 
Hengel, Martin. Judaism and Hellenism, trans.: John Bowden, (Philadelphia: Fortress Press, 1981).

Josephus, Flavius. The Works Of Josephus, trans.: William Whiston, (America: Hendrickson, 1999).

Kaufmann, Francine ve Eisenberg, Josy. "Yahudi Kaynaklarına Göre Yahudilik", Din Fenomeni, çev.: Mehmet Aydın, (Konya: Din Bilimleri Yayınları, 2000).

Kollek, Teddy. "Present and Future", Council on Foreign Relations, 59, 5, 1981, s. 1041-1049.

Kurt, Ali Osman. Fundamentalist Yahudiler, (Ankara: Eski Yeni Yayınları, 2016).

Maimonides, Moses. The Guide For The Perplexed, trans.: M. Friedlander, (London: Routledge\&Kegan Paul, 1951).

Mendelssohn, Moses. Jerusalem or on Religious Power and Judaism, trans.: Allan Arkush, (Massachusetts: Brandeis University Press, 1983).

Özen, Adem. Yahudilikte İbadet, İstanbul: Ayışı̆̆ı Yayınları, 2001.

Özmen, Seda. "Reform Yahudiliğinin Pittsburgh ve Columbus Platformları Bağlamında Değişen Kutsal Topraklara Dönüş İnancı", İsrailiyat: İsrail ve Yahudi Çalışmaları Dergisi, 2, 2018, ss. 82-101.

Philipson, David. "The Frankfort Rabbinical Conference 1845", The Jewish Quarterly Review, 18, 2, 1906, ss. 251-290.

Philo, trans.: F. H. Colson, (Massachusetts: Harward Press, 1985).

Rabkin, Yakov M. "Judaism: The Search for Peace in the Holy Land", Holy Land Studies, 10, 2, 2011, ss. 139-168.

Raphael, Marc Lee. "Rabbi Jacop Voorsanger of San Francisco on Jews and Judaism: The Implications of the Pittsburgh Platform", American Jewish Historical Quarterly, 63, 2, ss. 185-203.

Sanders, E. P. Judaism Practice E Belief 63 BCE-66CE, (London: SCM Press, 1992).

Shmueli, Efraim. "The Jerusalem School of Jewish History", American Academy for Jewish Research, 53, 1986, ss. 147-178.

The Apocrypha, (New York: Thomas Nelson\&Sons, 1804).

The Babylonian Talmud, eds.: Isidore Epstein, (London: The Soncino Press, 1935).

The Five Books Of Maccabees, trans.: Henry Cotton, (Oxford: Oxford University Press, 1832).

www.ccarnet.org/rabbinic-voice/platforms/article-declaration-principles/(03.02.2019).

www.ccarnet.org/rabbinic-voice/platforms/article-guiding-principles-reform-judaism/(03.02.2019). 